\title{
How We Got Here: The Transition of Colombia's Middle Class in Social Mobility Perspective
}

Consuelo Uribe Mallarino*, Liany Katerin Ariza and Jaime Ramirez Moreno

Institute of Public Health, Pontificia Universidad Javeriana, Bogotá, Colombia

\begin{abstract}
In this article, we present the results of a qualitative study on representations of social classes and social mobility between classes. The self-identified middle-class group attributes itself positive characteristics such as perseverance, entrepreneurship, work ethic, and consecration to an improvement plan. Staying in the middle class is perceived as a constant struggle to survive in an adverse economic, political and social context. The social relations between the classes are perceived as highly differentiated, with little mixture and a net desire to demarcate one from the others. The elements that structure social classes, according to this perspective, include education in the first instance, occupation, income, and the amounts of cultural and social capital accumulated in a variety of family and social conditions that vary by region and place of birth amid a common context of social policies and programs that are present for all social classes. The component that enables social mobility versus immobility for social groups of similar origin is the use of the fragile opportunities available throughout life. This is how the middle class is formed and recomposed in processes of upward mobility of low fluidity and little stability. This process, for some, has not been fully achieved in the present generation, but will only be achieved in their children's generation and in some cases, by sacrificing the expectations of parents and older siblings.
\end{abstract}

Keywords: Middle class; Class analysis; Social mobility; Inequity

\section{Introduction}

Contemporary research on social classes in Colombia is almost non-existent since few social scientists take this approach, except for some sociologists [1-3]. Researchers using the perspective of the social determinants of health [4]. In the Colombian case, there is also a confusion between the notions of social "class" and "stratum", as Uribe $[5,6]$ have pointed out, ambiguity derived from the wide acceptance among the population of the term from the policy of public utilities that obligatorily assigns a category to the residence of each Colombian according to variables of the infrastructure that surrounds their dwelling and giving rise to differential rates of public services and property tax, depending on the place of residence. This is how in the country the meaning of the concept of stratum is approached and confused with that of social class. Although the notion of "stratum" has not completely replaced that of "social class", it enjoys wide acceptance and both concepts are used in an alternative way. The interchanged use of the two is also widespread among agencies such as UNDP. For a few decades, most social scientists have considered the concept of "social class" to be useless for understanding social inequities [7-9]. Several authors emphasize inequality of gender, race, ethnicity, and sexual orientation over class differences, and some writers even blame the use of social class for obscuring obvious differences that were previously invisible $[10,11]$. However, other social scientists rescue the term as it the case with Wright [12]. It is also the main conceptual element in sociologists working on stratification and social mobility as Goldthorpe and Marshall [13], Hout, et al. [14] and, in Latin America, Torche and Wormald [15]. The use of the term is not very extended among economists, in contrast to sociologists and other social scientists, despite its broad acceptance by classic authors such as Marx, Ricardo, and Keynes. Although the notion is very useful in the study of social inequality, most economists who work on the subject avoid it and instead use data on income to obtain indices of severity and prevalence of poverty and income concentration, with categories defined by monetary limits in groups of similar size (quintiles and deciles of income). Recently, the acceptance of Thomas Piketty's analysis of capital in the twenty-first century has ingratiated the concept among economists. The author not only employs it, but performs an analysis of the current world social structure making a substantial critique of the prevailing social inequality model [16]. The concept has once again won adherents among social scientists and economists and has come to be useful for assessing the state of a country's social inequality. If a social class changes size, it changes the conditions of the other classes through the forms of distribution, increasing or decreasing the levels of inequality. In Latin America, organizations such as ECLAC and the authors around this entity returned to the use of the notion of social class since the mid-2000s [5,17]. However, it was due to its acceptance by agencies such as the IDB $[18,19]$ the World Bank the OCDE [20], the UNDP [21], CAF and similar entities [22-24] that the term "middle class" was fully enthroned in the economic heterodoxy. This has happened as the focus for studying inequality does not lie only on poverty but on all the changes in the forms of income distribution in the last ten years, which has received the bombastic denomination of the "gained decade". However, the definition of class continues to gravitate on the quantitative measure of income or on ex ante normative definition of poverty and vulnerability After decades of focusing on "poverty" and "the poor," these agencies have embraced the middle class as a safeguard of democracy, contributing to consolidate the rule of law and effective governance and fostering greater economic development [24,25]. The research on which this essay is based sought to investigate the expansion of the middle class in Colombia as a process of intergenerational social mobility. Given that the country comes from a recent past of a reduced

*Corresponding author: Jaime Ramirez-Moreno, Professor, Instituto de Salud Publica, Pontificia Universidad Javeriana, Bogotá, Colombia, Tel: +57 13208320 ; E-mail: ramirez.jaime@javeriana.edu.co

Received September 30, 2017; Accepted October 05, 2017; Published October 11,2017

Citation: Uribe-Mallarino C, Ariza LK, Ramirez-Moreno J (2017) How We Got Here: The Transition of Colombia's Middle Class in Social Mobility Perspective. Arts Social Sci J 8: 302. doi: 10.4172/2151-6200.1000302

Copyright: (c) 2017 Uribe-Mallarino C, et al. This is an open-access article distributed under the terms of the Creative Commons Attribution License, which permits unrestricted use, distribution, and reproduction in any medium, provided the original author and source are credited. 
middle class, its expansion must be understood as a situation that implies a process of change in social stratification. The essay presents the results of the qualitative component of a research project, designed to complement and deepen the quantitative component the project carried out over the analysis of the Quality of Life Surveys. The social change we are referring to - the expansion of the Colombian middle class - has elements of context (macroeconomic situation, employment, political stability, current social policy, etc.), elements of the situation to which individuals were exposed to in their life cycle, and elements related to the individual performance of people. This is imbedded in the context in which they conceive their lives through the passage of time in terms of their own accomplishments and the likelihood that this will happen to their children in the future. In this article, we will refer to the individual and contextual elements that contributed to people being represented in a social class, the way they define and live it and the interaction between "their class" with the other social classes in the dynamics of social differentiation. Social life takes place in an incessant comparison with their parents and the future of their children. In most cases of the people interviewed, belonging to the middle class is not something that just happened, but something in which they were active participants. This implies that there is a recognition of special conditions of each family group explaining that, subject to the same context, they manage to locate themselves in the middle class, while others do not. This requires analysis in the light of the agency that led these individuals to position themselves where they are Archer [26] and what Bourdieu calls the family strategies of social reproduction. However, despite the existence of mechanisms of upward social reproduction, staying in the middle class is lived as a continuous and uncertain struggle, in a social, political, and economic context that is read as unfavourable. In the first part of the article we describe the problems of the growth of the middle class in Latin America and in Colombia, and then present the methodology that we have followed in this study and then the results found. We end with a conclusion in the form of a reflection on what has been found in light of the social class approach that serves as a framework for interpretation in the study.

\section{The Expansion of Colombia's Middle Class in Social Mobility Perspective}

The research that gave rise to this essay stemmed from the confirmation of the growth of the Colombian middle class. Recent evidence indicates that there has been an expansion of the social group that is in the middle of the income distribution, generically termed "middle class", from $16 \%$ in 2002 to $26.5 \%$ in 2011, Angulo et al. [27] explained its increase was proclaimed by President Santos by the end of 2015 as one of the country's greatest social achievements, reaching $30.5 \%$ of the population and exceeding the percentage of the population in poverty (El Espectador, September 15, 2015). This process during the years two thousand and two thousand ten was not exclusive of Colombia, but occurred as well in other countries of Latin America. For the region, it went from $21 \%$ in 1992 to $26 \%$ in 2010 Ferreira et al. [28]. For the authors of this essay, the notion of social class is the cornerstone of the analysis that we propose. We conceive the social class not as a statistical measure, or a set of income-level ranks, but as a constructed category resulting from social interaction on the production and appropriation of economic, social, cultural, and political capital taking place across time. This results in hierarchical relations in social life, education, and culture and in the labor market [29], thanks to the imprint that habitus exerts on people in their assignment to the social space in which social classes are located [29]. For the authors of this article, the perspective of social mobility is adequate for approaching a phenomenon of social change as the growth of a social class, since it highlights the changes of income below the poverty line (US\$ 4.06 PPP); Vulnerable: households with a per capita income between the poverty line (LP) and US \$ 10 PPP; Middle class: households with a per capita income between US $\$ 10$ and US \$ 50 and High class: households with an income greater than US \$ 50 PPP. Ferreira et al. [28] use the same scale. Other agencies such as the OECD employ relative measures; the middle class includes households with a per capita income between 50 and 150 percent of the average per capita income. Consulted on July 31,2016. opportunity of life between one generation and the next, allowing the analysis to resist conjunctural variations by contrasting two groups of the same family origin, within a longer period. This perspective uses the observation of the transformations in time of social groups that change their position in the social hierarchy between the moment they are born (their social class of origin) and that which they achieve in adulthood (their social class of destiny).

\section{Materials and Methods}

The work presented here includes the results of the analysis of the narratives collected through five focus groups and a dozen interviews carried out in the framework of our research. The selection of the different people for participation in the focus groups and interviews corresponded to several criteria. The first one was that they were people of diverse income, educational levels, family formation and age, to deepen the representations and class experiences in different stages of the life cycle. The second, that the groups corresponded to clusters of different geographic origin (urban and rural). Then, five focus groups were formed: rural settlers, mothers over 45 , parents over 45 , young people studying in private universities and young people studying in public universities. In addition, we interviewed five informal workers (domestic worker, manicurist, street vendor, janitorial worker, and shoemaker), we conducted four in-depth interviews with participants in the focus groups, and an in-depth interview with an entrepreneur. To approach the representations of the middle class we adapted the methodology called the pragmatics of the judgment used in the framework of the "Inequalities Project" in Chile, which was in turn an adaptation of the methodology proposed by Boltanski and Thévenot [30] to study the justifications for social positions and inequality in France. This methodology proposes that people share a similar capacity to recognize the identity and distinctions between those who are part of a society that arises from socially defined and learned markers, which can be accessed by placing people in specific situations where they need to make use of the mental categories used to think society [31]. Seeking to recognize the way in which people in France believed that society was divided, Boltanski and Thévenot designed a game of cards with profiles representative of French society. These profiles had pictures and real information about age, place of residence, occupation, level of education of those represented. The intention was that, from these, classification exercises would be carried out in categories according to explicit and tacit criteria of the players [31-34]. In Chile, in the framework of the "Inequalities: trends and emerging processes in social stratification" project of 2011, the methodology was adapted to study the way in which inequalities are justified and to examine aspects such as representations of the middle class, moral borders, and tolerance of inequality in that country. In this project, the cards were designed from a sample contained in the National Survey of Social Stratification ENES. In total, 62 cards were designed each of which contained real information and a photograph of the person. These cards were used as a methodological resource in focus groups in which participants had to carry out several sorting exercises. We opted for this methodology 
to deepen the representations and constructions internalized and shared in relation to the definition of classes in Colombia, in the symbolic, historical, and material order. The main limitation for its development was not having sources of information that allowed access to information and real photographs of people. Based on information available in the databases of the National Department of Statistics (DANE), the demographic composition of the people participating in the 2008 Quality of Life Survey and the social categorizations built in the framework of this project, we designed several profiles in the form of cards, containing information about sex, age, occupation, educational level, place of residence, marital status and number of children of real people, information that was complemented with a designed image by an illustrator corresponding to the profile described [35-37]. After several processes of discussion and adjustment, we came to the definition of 42 profiles in the form of playing cards that were used as a methodological resource in the five focus groups. The members of the groups were divided into two teams requesting them that they organize the cards according to the way they considered the Colombian society is organized. After completing this exercise, we asked them to describe the main characteristics of each of the groups formed, the relationships between and with other groups. Subsequently, each team had to nominate the different segments, and then began to discuss the relationship between these groups and social classes, point to the one that was considered the middle class and name its characteristics with respect to the other identified groups. At the end of this stage, the teams were assembled in a single group to share their conclusions and discuss new elements around the classification of groups, their characteristic and relationship. We ended the focus group inquiring about the class self-classification of the assistants, as well as some aspects related to their life trajectory. To complement the information gathered from this exercise, in-depth interviews conducted later allowed us to have a more complete picture of the representations about the middle class and the dynamics related to social mobility. Based on the stories of the members of the groups and the interviewees, we performed a content analysis using N-Vivo software, which allowed us to establish categories and concepts that were extracted from these narratives [38-40].

\section{Results}

The results are presented in four sections. The first one describes the elements that determine the membership of a social class and how they are articulated and differentiated in interrelationships and hierarchies of power, as well as their main forms of representation of being where they are. In the second, an analysis is made on the foundations of class division and its forms of interaction. In the third, the characteristics of the middle class are outlined. And in the fourth, the channels on which social mobility occurs and, in particular, the one in which the middle class is a protagonist [41].

\section{Determinant Elements for Belonging to a Social Class}

Although in the different focus groups and interviews the profiles were organized and classified in different ways, four elements emerged as determining the conformation of the classes in Colombia, which, in turn, would allow to explain the social differences: the educational level, the occupation, the geographical and public policy environment, and the capital endowment of the families of origin. All this would be driven or hindered by the individual response to the social opportunities that are presented. Income was noted as important, but not as a determinant of social classes, but if, linked to occupation, would constitute two of the most important elements, but not exclusive, of social differentiation. Occupation and income are, in turn, related to education, since the quality of employment and its remuneration enable an income that differs according to the educational level attained. However, it is not a question of any access to education, but of insertion into reputable schools of primary and secondary education, especially private ones, that favor better education. Complementarily, as in a circular movement, income would depend in turn on the quantity and quality of education and access to it, in turn, depends on income, thus sealing the circularity of the process of reproduction of social inequalities in the country. The education thus obtained would also depend on the insertion in the job market. Those who hold management positions, managers or have formal jobs are those who get to place themselves in better social positions, obtaining higher incomes. The quality of labor insertion would also be related to the possibility of buying material goods, saving, investing in education, requesting credits, etc. On the other hand, getting less education would imply that the work performed will require greater physical effort and attrition of the body, with negative consequences for health, obtaining lower income and, therefore, occupying a lower social position. Manual occupations are at the bottom of the wage and income scale, and a dignified employment is largely related to the formality of labor, since labor norms only apply to those who have a work contract and are covered by social security protection in the form of pensions and health services. It also implies that the labor code regarding minimum hours of work, holidays, bonuses and "cesantía" is applied. Some of the self-employed workers at the professional level achieve relative equality with employees in terms of social protection, but at a high cost, and not always continuously. Education would also be the central element in establishing contacts and social networks, to develop skills and abilities to learn, be innovative and make decisions about the children's future and for the investments to be made. In any case, the process of social positioning and its references to social locus is shaped by a diversity of social, economic, cultural and political relations that manifest simultaneously over time and whose opportunities can be taken advantage of through self-effort. The family context is invoked as intervening in belonging to a social class, with its various aspects of wealth (economic capital), relationships and networks (social capital) and preferences and cultural tastes (cultural capital). These elements are very important because they intervene at an age in which individuals cannot decide for themselves and are subjected to the choices that parents and family make for them. In Colombia, "cesantia" is a severance payment given to the salaried worker at the termination of employment even when the worker decides quitting; it corresponds to a salary per year worked or fraction, plus interests, paid by the employer. The above-mentioned elements determining the belonging to a social class are both individual and collective. The educational level and the occupation, as well as the income derived from it, are perceived at first as of the individual sphere, but they depend, in time and in the social space, on the family and the social environment, which in turn interact with the social, economic, and political context. The interaction of these elements revolves around the ability to take advantage of the opportunities presented to individuals and families. It is not just subsidies or services for the poor and vulnerable, but global opportunities for access to work and education, some of which depend on the context in which people live and others present themselves as challenges that are offered, promoting a transformation in the life cycle. In Figure 1 we present a graphic representation of the elements that would determine social class composition in Colombia. For our interviewees if they were asked to summarize the Colombian social classes in a basic scheme, they would include three conglomerates: upper, middle, and lower class. This classification would have some more specific and illustrative gradations of the hierarchical social world, depending on the capacity to take, 


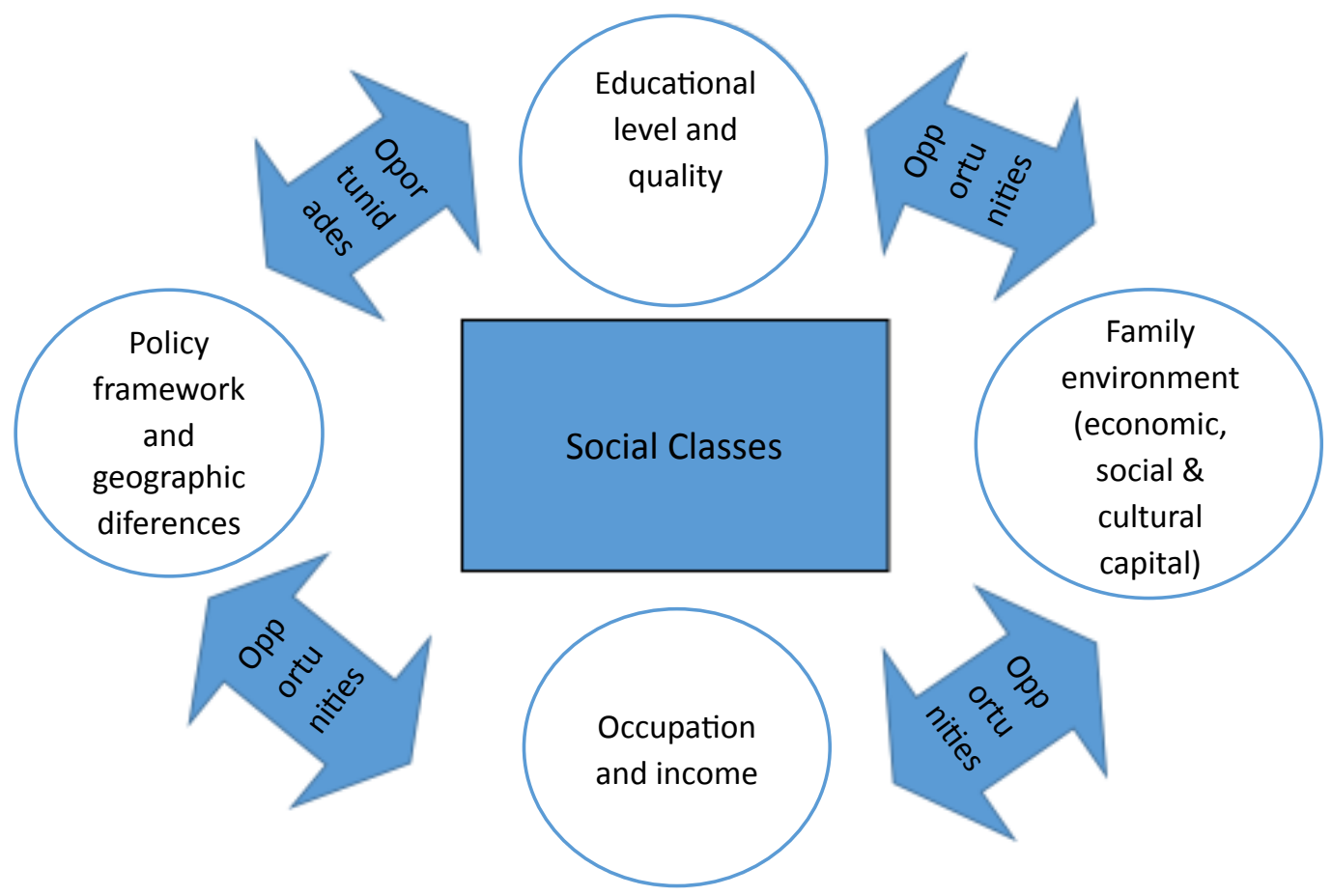

Figure 1: Diagram of elements identified as determinants of social inequality in Colombia.

and exercise the opportunities presented and to obtain achievements from the challenges that this entails. Moreover, it could be said that poor rural residents are classified as a separate social class, since the context opportunities are clearly deficient compared to those of urban residents. Likewise, the geographical area influences the opportunities that present themselves, because it is not the same to be in Bogota as in a provincial city with a lower offer.

This basic scheme would have the following gradations, according to the ability of these conglomerates to address the opportunities presented to them:

- Entrepreneurs and those who have overcome: People characterized by working and studying, who are constantly looking for new opportunities in life. Also, people who have managed to transcend adverse situations and have been able to reach different goals. This category includes people who have been in debt to improve what they had, have paid their loans, and moved on.

- Those with luck and talent: people who, without having completed a high school education or higher, thanks to their personal abilities, have formed businesses or have been promoted in their jobs.

- Those on the limbo or without improvement: People who have remained in unfinished educational processes, have intermediate jobs, and / or have not defined what they want to do. It also includes those who have been satisfied with what they have achieved, so they do not improve their living conditions.

- Those that lacked opportunities: Those people who have not had opportunities in life to study, work, or have low income. Poor rural people are the most likely to be in this category.

- Those who have it all: this is the elite that has not had to fight to get where it is and whose opportunities place them at the top of the social scale of hierarchies.

\section{Social classes and their structuring elements}

Social classes in Colombia are seen as a system of complex positional hierarchies, with complementarity in the mechanisms of social reproduction of one class in respect to the others. The two main characteristics are identified as follows: the first, that preferential and direct interaction tend to happen between peers, between equals, between those who share similar economic conditions and educational levels, since only between people alike it would be possible to establish relations of friendship or neighbourhood. And second, that the interaction between people of different social classes is limited and tends to occur preferentially in job interactions, in which some work for others; it can also occur in market scenarios, through the sale and consumption of products, but in general, there are no wide geographical spaces of occurrence of meeting between people of different classes. It is noticeable that the only scenarios of interaction between people belonging to different social classes are identified in job relations, in which hierarchical relationships and subordination are the norm. The sale of goods also occurs in a segmented way because the places where it takes place are segregated and the capacity of payment that accompanies the access to these products depends on the social class. This is accompanied by a marked social fragmentation, which would be internalized in the way they relate to one another. In the identification of the national social landscape, Colombia is conceived as a society in which the differences are deeply marked among the classes. The lower classes would concentrate the most difficult social conditions and the least opportunities for access to full and quality education and jobs that provide stability, social security and sufficient economic income. For its part, the upper class would take advantage of opportunities, economic resources and also political power. Finally, the middle class would be characterized by being among the extremes of social stratification, but 
not in easy conditions, emphasizing that in order to be and remain in this social group its members must make a constant effort to be there and, often, have to borrow for achieve it. To be between the extremes is not to live in the conditions of comfort and diversity as they are expressed a priori quantitative studies that exogenously attribute characteristics to the middle classes, desirable for the whole of society. To be between the extremes is neither a necessary bridge through which all the classes must cross and is not always seen as the natural channel of the rise or the social descent. The social world is perceived in a simple way, but in complex and unmodified hierarchies throughout time. As for the values of members of the different classes, those of the middle class declare that they have no moral problems in relating to the lower classes. On the latter, and especially the peasants and rural inhabitants, their values such as solidarity, companionship and mutual help are highlighted, and conceived as necessary to survive in the face of adversity. In contrast, people of the upper class are generally represented negatively, emphasizing that they do not interact with other social groups and that they exert a marked social segregation; when they do have an is interaction, it not be in terms of equity or respect but rather in terms of social segregation, superiority, and exclusion. A recurring element in explaining a person's belonging to a social class is the ability to have control over his/her live. This control would involve the power to decide on his/her subsistence and his/her bodies, a particularly important aspect for women when they can decide when and how many children to have. The control people can have over their own life concerns the ability to plan the future, which increases when ascending the social ladder. An integral part of the middle-class way would involve its relative ability to plan the future and direct its actions towards the proposed objectives amidst lower levels of uncertainty. In contrast, lower-class people see themselves as living in a world of great uncertainty and pessimism, with little control over their lives, and they are forced to resolve day-to-day life in terms of survival.

\section{Conformation of the middle class}

As for the characteristics of those who position themselves in the middle class, it can be said that they have had the opportunity to obtain more years of education than the average, some in private institutions, which, according to them, provide a higher quality education than public schools, particularly in primary and secondary education. It is a class that stands out for being educated and "well" trained, which allows them to access, on the one hand, more formal jobs with administrative and coordination positions and, on the other hand, higher remuneration compared to the one received by the lower class. It stands out that they are urban settlers, so it can be said that there is no rural middle class. Despite these better relative conditions and greater opportunities, it is also recognized that the middle class strives day by day to stay in that class and not to fall; In a certain sense, it is a vulnerable class, which is always in danger due to the conditions of the country, tax reforms and the lack of employment and job stability. To be better does not mean to be well, given the fragile condition of their position, characterized by an effort and sacrifice of a generation that intends to guarantee to their children or younger brothers and sisters levels and social opportunities that do not depend on chance and luck. For this class, education is a priority, an investment in the future. Therefore, its members strive to obtain the resources that allow them to pay for quality education. It is worth noting that, in order to improve their living conditions, this class resorts to indebtedness and the sacrifice of their own achievements, particularly to pay for the children's university, to buy housing or cars. For those who place themselves in the middle class, this class would be made up of "hardworking, enterprising, and studious people, who have improved themselves", as well as those with "luck and talent".
They would distinguish themselves from other groups by the desire and constant search to progress, and improve their living conditions and those of their families. Also, because they are people with great tenacity, able to face different challenges during their life. Likewise, they are characterized by searching the union and well-being of their family, having the capacity and possibility to plan the future, an intent decision on how many and when to have children and how to invest the resources. Regarding children, it stands out that their number per household is lesser than the one their parents had, to be able to offer them a better future. At the level of political practices, most of the participants who declare themselves as middle class show their support for participatory democracy as a form of political organization. However, they showed objections to the way it occurs in the country. Some participants, for example, spoke of the fact that there is no real democracy in Colombia, since both the election process and the way in which politicians play their role do not benefit the majority or solve big problems such as unemployment. A majority group of self-identified middle-class people indicate that they have participated in electoral processes for president, mayors, congressmen, etc., emphasizing the importance of voting as a way to influence the destinies of the nation. However, when assessing the dynamics that occur during these processes, lack of awareness of those elected for office is highlighted, as the pursuit of individual and immediate benefits would be a common trait of both elected politicians and appointed authorities, generating practices such as purchasing - sale of votes, which subtracts legitimacy to the process of popular election. Middle-class people feel little representation of those currently occupying popular election positions, whom they referred to with qualifications such as "corrupt" and "thieves." Linked to political representativeness is the idea that people in power only represent the interests of their own class, i.e. the upper class. The state appears as an actor who does not help the middle class; on the contrary, it limits the possibilities of its social ascent, particularly by tax reforms that extract taxes from the middle-income sectors which, in the last years, have affected their income. Among the tastes and cultural consumption middle-class members say that they can "with effort" travel, eat in restaurants, go to the movies, concerts, and bars where an entrance fee is charged. They would devote their free time to share with friends, family, and activities such as playing billiards or soccer, watching television, among others. Although it is not stated explicitly -because each group refers to its own situation- the middle class perceives itself with some heterogeneity when it comes to its relationship with the upper class and the lower or popular classes, some being closer to the former and some being closer to the latter. The feature that was most emphasized is that those in the middle class have reached their rank thanks to their own effort, their availing the conditions offered in the context and their interaction with other social classes, albeit an environment of uncertainty towards the future and the risk of losing the wellbeing reached.

\section{Social Mobility}

Social mobility is a desired asset when it comes to upward mobility, but the possibilities for downward mobility are real and a constant threat. Upward social mobility was identified as being mainly linked to two characteristics and / or situations: effort and entrepreneurship; as well as two elements of context: the family and the place of origin in the framework of hierarchy relations. At a personal level, the middle class is represented as a destination class that was reached after hard efforts over long periods of time, whose members are able to hold some control over their lives, which, combined with further schooling and proper use of social networks, helped them to ascend socially. They feel that they 
experience life differently from the lower class and they value especially the effort made and the use of opportunities they took advantage of. However, their upward mobility occurs in a moderate way and with a lot of vulnerability. The role assigned to the State in relation to social mobility is partial and limited, especially since it does not provide the conditions of opportunity necessary for people to access education, jobs and health care. The "spirit" of entrepreneurship is also important for social mobility processes to occur, as it is a feature that enables people to take initiatives, pursue opportunities and start businesses. Personal effort would be the way to materialize the enterprise from the use of opportunities, the search for study options and new and better jobs. Among the contextual elements, the family of origin is identified as a factor strongly linked to social mobility, as it would act as a scenario of limitations and opportunities, accumulation of social, cultural, and economic capitals inherited by the younger generations. The family would act as a propitious frame for the accumulation of wealth and power, constituting a scenario of social reproduction, particularly for the options of schooling and access to economic, social, and cultural capital that this nucleus would provide. Participants of the focus groups mentioned practices within the household for the survival of the family structure that include the "sacrifice" of the older sons and daughters, so that the younger children can study, which can influence the dynamics of differential social ascent between siblings of the same household. In this class, as in the other classes, we found that having family networks is a fundamental element to overcome adverse conditions. Also, for thriving at work and education and for childcare. The place of birth is also recognized as linked to social mobility processes. It is pointed out that those living in rural areas have less access to education and jobs and therefore have lower incomes. Given the above, migrating from the countryside to the city, and particularly to the capital, was identified as a strategy favoring upward social mobility. This mobility is limited to the extent that each class helps itself and its relations with other classes are determined not by a spirit of solidarity and by benevolence but by social and market needs, either through the labor market or through the relations of production or in the market of goods and services when it comes to the exchange of consumer or intermediate goods. Other aspects related to social mobility were identified as linked to both personal decisions and to living conditions. Thus, a reduced number of children is identified as an element that favors social mobility, better conditions for the neighborhood location of the house, better food, more and better education and more leisure activities. Having a partner was identified as another element that favors social mobility within the household, since it would involve two people contributing to the support and education of the children. On the contrary, being a single mother is recognized as an aspect that would limit social mobility, as it would be a single person in charge of educating and providing for the needs of the household. Technology as a means to connect with the local and global world is recognized as one of the channels to access knowledge, employment opportunities, social networks, and information, which would be key for upward social mobility. It was mentioned that access to it is very unequal between rural and urban areas and between social classes. The ability to establish and maintain social networks and contacts with peers and superiors is also identified as an essential element for social ascent processes, particularly for creating networks and for the smooth running of business. The level of opportunities becomes more complex because these would also increase or decrease according to the level of schooling. On the other hand, with higher schooling and greater and closer family relationships, the chances of having a better job, better income and more strategic social networks increase; on the contrary, lower levels of education would affect the quality of employment and, therefore, income. The element allowing the articulation of individual and contextual characteristics linked to social mobility is opportunities. In many cases, the social world appears as a set of "small opportunities" thanks to which some groups "make it" whereas others have always been there because they are those who "have it all." It was recognized that those from the less privileged groups of society and those who do not live in the cities endure deficiencies or limitations in opportunities, particularly in relation to study and work. People living in cities, as well as those born in households with high economic resources, as well as important social and cultural capital, are said to enjoy opportunities that guarantee food and livelihood, as well as more and better education. The feature of the elite would be to have a broader set of social, economic, cultural, and political opportunities that guard it against uncertainty in future outcomes by addressing risks in a collaborative way as a class and by establishing social networks that favor its permanence in the upper echelon of the social scale. In the perspective of opportunities as a chance or as a situation found in the context, chances cease to be something external to the subjects and move to the internal plane in which the subject's will has the potential to define the place he or she will occupy in society. An example of this would be the migration to the cities from the countryside or to the big cities from small towns, which would be one of the opportunities taken to improve life conditions, a move that is not used by everybody. The interaction of education, place of birth, family of origin, occupation, effort, and entrepreneurial spirit with the individual response to arising opportunities, produces the plot that explains the processes of social differentiation in terms of greater or lesser uncertainty. This would be the mechanisms that allows individuals and families a probable future of social ascent in which they can leave behind living only a day at a time. When asked those self-classified as middle class about the assessment they make of their lives, one part acknowledges that they did not achieve everything they set out to do; however, they are satisfied with what they've achieved, the product of their work and effort. They mention that the realization in their lives begins to occur not only through their own achievements but through the achievements of their children, which they also helped to forge. That is, it becomes clear that social mobility requires a long-term chronology, and requires taking a multigenerational perspective.

\section{Conclusion}

There are numerous articles and indicators that point to Colombia as one of the countries with the greatest social inequality in the world, so it seems counterintuitive that there has been an expansion of the middle class in the middle of such a concentration of income. In this paper, we present the narratives constructed around the way in which a complex social phenomenon of social mobility takes place in an environment of high social inequality. We have shown that the division of classes in Colombia is acute and forms part of a sphere of high social differentiation, where social interactions between different classes are few and, when they occur, take place in an environment of disrespect and lack of solidarity for the others and is limited to forms of market exchange either through labor relations or trade of services and consumer goods. The class structure would comprise three groups whose colloquial denomination designate them as the lower, the middle, and the upper class. The interrelations express differences and social positions marked by the naturalization of inequality, exclusion, and hierarchy. Personal and collective or social characteristics intervene at the base of Colombia's class structure. The distinctive characteristics at the personal level include the educational level obtained at the end of the school years and the occupation in which the workers inserted as adults, which results in differential income in a sort of circular 
process that combines the conditions of the people with the social opportunities of the market, as well as inter-family relations as a norm and some inter-class relations, as an exception. Social features include the family environment of the home of origin, with the different amounts of social and symbolic capital held, including economic, social, and cultural. On the other hand, existing public policies regulate labor relations, and the provision of social services such as education, health, utilities, and security. Finally, the geographical area in which one is born determines the options of opportunities in all areas. The interactions between these individual and collective elements are such that they mutually reinforce each other and produce very diverse results on social inequalities. The elements that articulate these elements are given in the form of opportunities, some of which can be used, some of which not. Education would be the determining factor explaining social differences, but it is not the only one, since it is necessary to land a good job in order to transform the effort into valuable income, as well as to achieve better family and social relationships. Private basic education is attributed with benefits that public education does not ensure, both for its quality and for the social network to which it gives access. On the other hand, manual jobs involving physical effort are not only identified as the only ones open to those with lower schooling, but also leading to an informal job insertion without social protection and outside the labor norms, producing vulnerability and poverty. Our study indicates that the members of the middle class qualify their own moral conditions and values as positive, to which the best qualifiers are given: entrepreneurs, fighters, achievers, that is, people who have had the merit of reaching the rank and to stay there. The Colombian middle class would be reached by a deliberate and constant effort, with tenacity, dedication to study and discipline. In a context of marked segregation and concentration of wealth, the upper class is marked with negative attributes: indifferent or disrespectful, segregationist, indolent, associated with the political class around a confluence of interests which, in turn, is qualified as "corrupt" and "thieves ". This ends up undermining the confidence in institutions, the electoral process, democracy, and the political regime as a whole. The political, economic and social regimes and the opportunities for realization do not stand alone in society, but are shaped and reproduced according to the social class to which you belong. Social mobility in Colombia would be the result of the articulation between personal and social variables in which the capacity of agency or action allows to mark differences around the opportunities presented. In this sense, our work indicates an affinity with the proposal of Sen (1992) to propitiate the capacities of the individuals in terms of the freedom to choose what they really value and to have the means to obtain them. The ability to plan and control their own lives was highlighted in our study as an essential element to be a part of and to remain in the middle class and, therefore, in favor of upward social mobility. In fact, the lesser or greater ability to control the own present or the future would be at the basis of social differences in the country. The study offers useful elements for understanding social realities throughout the life course of people, as a result of events occurring over time. This requires a time of realization that comprises several generations in opportunities of education, jobs, occupation and family and social relationships. These relationships are perceived as unequal and closed, for which social mobility requires the consistency of the effort made by families and their social nucleus to face the uncertainty of the future and social segregation. Historically, the middle classes are perceived as a point of arrival, in which permanence is not an easy matter, because the vulnerability is always present with a threat to lose the position achieved. The action of the state and the prevailing social policies fail to provide conditions of social stability, and are unconducive to upward mobility. In most cases, they are perceived as siding and being in close alliance with the upper classes in a non-transparent way.

\section{References}

1. Alvarez Rivadulla MJ (2016) Tolerance to Inequality in Latin America: An Exploration in Montevideo and Bogota. Ensambles Magazine 1.

2. Castellani F, Parent G (2011) Being 'Middle class' in Latin America, OECD Working Paper No. 305.

3. Fresneda O (2012) Las Desigualdades En La Calidad De Vida Por Posiciones De Clase Social. In: Fresneda O (ed.) Equidad En Calidad De Vida Y Salud En Bogotá: Avances Y Reflexiones, Bogotá: CID, SDS. 55: 104.

4. Alvarez-Castaño LS (2014) The Social and Economic Determinants of Health Theoretical and Methodological issues involved in the analysis. Journal Management and Health Policies 13: 28-40.

5. Uribe C (2008). Estratificacion social en Bogotá: de la politica publica a la dinamica de la segregacion social. Universitas Humanistica 65: 139-171.

6. Uribe C, Pardo C (2006) La ciudad vivida. Movilidad espacial y representaciones sobre la estratificacion social en Bogota. Universitas Humanística 32: 169-203.

7. Clark T, Lipset S (1991) Are Social Classes Dying? International Sociology 6 : 397-410.

8. Pakulski J, Waters M (1999) The Death of Class. The Canadian Journal of Sociology/Cahiers Canadiens de Sociologie 444: 446.

9. Kingston P (2002) The Classless Society, from Contemporary Sociology Stanford. Vol. 31 Iss. 3 267: 268.

10. Quijano A (1998) La colonialidad del poder y la experiencia cultura latinoamericana, from Briceno \& Sonntag (eds), Pueblo, epoca y desarrollo. Caracas: Nueva Sociedad.

11. Mignolo W (2013) La Colonialidad a Lo Largo Y a Lo Ancho: El Hemisferio Occidental En El Horizonte Colonial De La Modernidad.

12. Wright EO (1997) Class Counts: Comparative Studies in Class Analysis Cambridge: Cambridge University Press.

13. Goldthorpe J, Marshall G (1992) The Promising Future of Class Analysis Sociology. 381: 400

14. Hout M, Brooks C, Manza J (1993) The Persistence of Classes in Postindustrial Societies. International Sociology. 259: 77

15. Torche F, Wormald G (2007) Chile, entre la adscripcion y el logro. Estratificacion y Movilidad Social en America Latina, from Franco R, Leon A, Atria R. Santiago de Chile: LOM: 339-385.

16. Grosjean B, (2011) Thomas Piketty La Lutte De Classes n'est Pas Morte Rue89 - L'Obs.

17. Franco R, Hopenhayn M, Leon A (2011) Crece Y Cambia La Clase Media En América Latina: Una Puesta Al Día. Revista CEPAL No. 193, abril de. 7: 60.

18. Stampini M, Marcos Robles M, Saenz M, Ibarran P, Medellin N (2015) Pobreza, vulnerabilidad y la clase media en America Latina. Washington: Inter American Development Bank Work Document No. 591.

19. Castellani F, Parent G, Zenteno J (2014) The Latin American Middle Class: Fragile After All? Washington: Inter-American Development Bank.

20. OCDE (2010) Latin American Economic Outlook 2011: How Middle-Class Is Latin America? Paris: OECD Publishing.

21. UNDP (2012) Perfil de estratos sociales en America Latina: pobres, vulnerables y clases medias. Santiago de Chile: PNUD.

22. Lopez-Calva L, Rigolini J, Torche F (2012) Is There Such a Thing as Middle Class Values? Working Washington: Center for Global Development.

23. Lopez-Calva L, Ortiz-Juarez E (2013) Clases Media y Vulnerabilidad a la Pobreza en América Latina. Pensamiento Iberoamericano 49: 70

24. Birdsall N (2012) A Note on the Middle Class in Latin America. CGD Working Paper 303. Washington, DC Center for Global Development.

25. Cardenas M, Kharas H, Henao C (2011) Latin America's Global Middle Class: A Preference for Growth over Equality, Washington, DC: Brookings Institution.

26. Archer M (2003) Structure, Agency and The Internal Conversation. London: Cambridge University Press. 
Citation: Uribe-Mallarino C, Ariza LK, Ramirez-Moreno J (2017) How We Got Here: The Transition of Colombia's Middle Class in Social Mobility Perspective. Arts Social Sci J 8: 302. doi: 10.4172/2151-6200.1000302

Page 8 of 8

27. Angulo R, Gaviria A, Morales L (2014) The Decade Gained: Evolution of the Middle Class, Poverty and Vulnerability in Colombia 2002-2011. Economic Conjuncture 44: 173-209.

28. Ferreira F, Messina J, Rigolini J, López-Calva LF, Lugo MA, et al. (2013) La Movilidad Económica Y el Crecimiento De La Clase Media En América Latina. Washington: Banco Mundial.

29. Bourdieu P (1976) Marriage Strategies as Strategies of Social Reproduction Baltimore: The Johns Hopkins University Press.

30. Boltanski L, Thevenot L (1983) Finding One's Way in Social Space: A Study Based on Games. Social Science Information 22: 4-8.

31. Mac-Clure O, Barozet E, Carvajal P, Dary S, Figueroa N, et al. (2012) Justicia Social Y Tolerancia a la Desigualdad: Análisis Subjetivo De La Diferenciación Social En Un Regimen Neoliberal Maduro.

32. Aguilar MA, Roa IC, Kaffure LH, Ruiz LF, Sánchez G, et al. (2013) Social Determinants of Health: Official Position and Critical Perspectives. Rev. National Faculty of Public Health 31: S103-S110.

33. Avanzini D (2012) Middle Class and Fiscal Policy in Latin America. ECLAC Development Macroeconomics Series No. 123.
34. Bourdieu P (1984) Distinction: A Social Critique of the Judgment of Taste. Cambridge Mass.: Harvard University Press.

35. Castellani F, Parent G, Zenteno J (2014) The Latin American Middle Class: Fragile After All? Washington: Inter-American Development Bank.

36. Castellanos J (2010) Una vision Multidimensional of the notion of social class Journal of Anthropology and Sociology 12: 63-87.

37. Giddens A (1975) The Class Structure of the Advanced Societies. New York Hagerstown, San Francisco, London: Harper and Row Publishers.

38. Grosjean B (2011) Thomas Piketty La Lutte De Classes n'est Pas Morte. Rue89 - L'Obs.

39. Penfold M, Rodriguez G (2014) La Creciente pero Vulnerable Clase Media de América Latina. Patrones de Expansión, Valores y Preferencias. Serie Políticas Públicas Y Transformación Productiva №17 Caracas: Corporación Andina De Fomento.

40. Sen A (1992) Inequality Re-examined. Oxford: Clarendon Press.

41. Sembler C (2006) Estratificacion social y clases sociales. Una revision analitica de los sectores medios. CEPAL Serie Políticas Sociales No. 125, Santiago de Chile: CEPAL. 